Arboriculture \& Urban Forestry 2014. 40(6): 345-350

\title{
Preventing Death and Taxus: Review and Recommendations for Managing Taxus in the Landscape with Overview on Phytophthora cinnamomi, Soil, and Nutrition Status
}

\author{
Matthew D. Taylor
}

\begin{abstract}
At least three major gardens or arboreta in the USA have experienced periods of significant decline and death of mature Taxus (yews) in the landscape. The symptoms displayed on declining plants are described as chlorosis of the needles, partial defoliation, and death of some of the branches. Eventually, the entire plant may die, but they are typically removed before reaching this stage. Information on managing mature Taxus in the landscape is limited. The objective of this article is to review the literature on Taxus cultural practices and use the information to develop best management practices for Taxus in the landscape. Soil moisture is the most critical factor for health of plants in the landscape. Saturated soils create anaerobic conditions for roots and create an environment ideal for root infection by Phytophthora cinnamomi, the major root pathogen affecting Taxus. During planting, proper site selection and well-drained soil are crucial for the longterm survival of plants. After planting, irrigation should be managed to avoid saturated soil. Management from a nutritional standpoint is poorly understood. Maintaining an appropriate $\mathrm{pH}$ of 6.0 to 7.0 and fertilizing plants based on soil and tissue testing is recommended. More research needs to be done to determine optimal fertilization rates and appropriate nutrient concentration in tissue and in soil. When plants become symptomatic, soil should be tested for P. cinnamomi. If the fungus is present, appropriate chemical controls should be used.

Key Words. Manganese; Phytophthora cinnamomi; Plant Nutrition; Root Rot; Taxus; Water Management; Yew; Zinc.
\end{abstract}

Taxus, or yews, are popular landscape plants due to their slow growth habit, dark evergreen foliage, pest resistance, and tolerance to sheering. At Longwood Gardens in Kennett Square, Pennsylvania, U.S., Taxus are an integral component of the outdoor displays. As of 2014, Longwood's Taxus collection included 330 accessions composed primarily of three species: Taxus baccata, Taxus cuspidata, and Taxus $\times$ media. More than half of the specimens in this collection are over 50 years old.

Over the past several years many of the mature Taxus at Longwood Gardens have begun to show signs of decline at a rate that hadn't been recognized in years prior. Since 2006, 78 Taxus accessions have been removed from the gardens. The reasons for removal may include: garden renovation, storm damage, disease, declining health, and death. Unfortunately, the definitive reason for removal of each of these accessions was not always deter- mined or recorded. Therefore, researchers cannot say for certain that there has been a higher incidence of decline or death of Taxus in the landscape at Longwood Gardens. The symptoms displayed on declining plants are described as chlorosis of the needles, partial defoliation, and death of some of the branches. Eventually, the entire specimen may die, but they are typically removed before reaching this stage. Upon removal and inspection of the roots, many of the plants exhibited blackening and rotting of the root system. This indicated Phytophthora infection, which was confirmed through serological tests on six of eight plants (University of Minnesota, Plant Disease Clinic. St. Paul, Minnesota).

At the New York Botanic Garden (NYBG) (Bronx, New York, U.S.) and the Arnold Arboretum (Boston, Massachusetts, U.S.), similar situations have occurred, where a significant number of Taxus specimens declined and/or died in the landscape 
(Hibben and Cahilly 1996). From 1982 to 1992 at NYBG, a total of 28 Taxus began to decline and were removed from the grounds. A similar event also occurred at Arnold Arboretum in 1990. At both locations, Phytophthora cinnamomi Rands was identified in the roots of the Taxus and was thought to be the causal agent. This rapid decline and loss of Taxus plants at two of America's premier public gardens prompted a three and a half year study to determine the possible cause. The experiment examined 71 specimens of Taxus at NYBG for needle loss, tip dieback, winter injury, needle distortion, branch dieback, arthropods, air pollution, disease, and plant nutrition. This extensive examination noted many types of stress that can affect the health of Taxus in the landscape. However, no definitive cause was determined nor were any strong trends associated with needle chlorosis or poor plant health. Furthermore, symptoms of Phytophthora root rot were not discovered, even though specimens were still in decline during this period. One explanation for this was that during the 1982 to 1992 period, all susceptible specimens had been removed, and infection during the study was at a low level.

The objective of this article is to review the literature on Taxus cultural practices with a focus on water management, root rot caused by P. cinnamomi, and plant nutrition. Researchers hope to then use the information to develop best management practices to maintain and possibly improve the health and longevity of mature Taxus in the landscape.

\section{WATER MANAGEMENT AND PHYTOPHTHORA CINNAMOMI}

Water management is considered the most critical factor for the health of Taxus during production and in the landscape. The primary cause of death of plants in the landscape is high soil moisture, which is typically caused by poor soil drainage (Ellis et al. 1993; Fraedrich 1999; Kaiser and Ward 2013). Saturated soils can cause anaerobic conditions in the root zone and starve respiring roots of oxygen. Furthermore, saturated soils create an environment ideal for Phytophthora sporangium production, zoospore release, and subsequent root infection (Matheron and Mircetich 1985; Benson 1986; Agrios 1997; Dumrose and James 2005). In nearly every part of the world where soil becomes too wet for a particular plant, Phytophthora can cause damage in hosts ranging from vegetable seedlings to mature woody plants (Agrios 1997). Once the fungus enters the root, it grows in the cambium and kills plants by debilitating water and nutrient uptake (Smiley et al. 1999). This can sometimes cause a very rapid decline in the aboveground portion of the plant. Young plants that are infected can die in just a few days, whereas older trees may take several months to years before they die. This depends on the environmental conditions and the amount of Phytophthora present in the soil (Agrios 1997).

Root disease on Taxus caused by Phytophthora was first described by Crandall (1936). In particular, Crandall found P. cinnamomi on several species of Taxus in several eastern U.S. states. The first signs of the disease were described as the loss of green needles and wilting of young shoots. However, Crandall did not link the occurrence of the disease with any particular environmental conditions. Schreiber and Green (1959) determined P. cinnamomi was causing the death of Taxus propagules, production liners, and older plants in the field. Symptoms were described as the gradual loss of mature green color, dieback, and occasional wilting of young shoots. The root systems also showed extensive discoloration of reddish-brown to black. Authors also indicated disease incidence was most severe under conditions of high soil moisture or other environmental conditions detrimental to root development. Ellis et al. (1993) observed brick red lesions on roots of T. cuspidata and $T . \times$ media that were also showing the previously described above ground symptoms. Phytophthora cinnamomi was recovered from the roots and Koch's postulates were used on two year old transplants of T. $\times$ media to determine this was the fungal agent causing dieback, root lesions, and reduced growth.

In addition to soil moisture, soil temperature also has a significant effect on the pathogenesis of P. cinnamomi (Zentmyer 1981). Waterhouse (1963) indicated $P$. cinnamomi has an optimum growth temperature of $26^{\circ} \mathrm{C}$. In a study with avocado, $P$. cinnamomi reduced growth when soil temperatures ranged from $15^{\circ} \mathrm{C}$ to $27^{\circ} \mathrm{C}$ with optimum infection rates occurring when temperatures were above $21^{\circ} \mathrm{C}$ (Zentmyer 1981). In a container study with azalea [Rhododendron obtusum (Lindl.) Planch.], root rot caused by $P$. cinnamomi was more severe when containers were exposed to sunlight, which could be due to higher soil temperatures (Benson 1986). These studies indicate temperature is a critical fac- 
tor for the growth and pathogenesis of $P$. cinnamomi and should be a consideration with implementing a management strategy for control or prevention.

\section{SOIL AND PLANT NUTRITION}

The physical properties of soil are very important for the health of Taxus. As discussed above, saturated soils are detrimental to the health of Taxus and water-holding capacity is directly related to soil particle size. In general, the greater the clay content of soil, the greater the water retention. As the sand component of the soil increases, the air-filled pore space increases and water-holding capacity decreases (Hillel 2008). Heavy clay soils and areas of poor drainage should be avoided when planting Taxus. It seems logical that if clay soils exist, amending with sand will improve drainage. However, this is not the case, and adding small amounts of sand to clay soils creates a soil structure similar to concrete and will not improve drainage ( $\mathrm{Da}$ vis and Whiting 2013). Amending clay soils with organic matter will improve drainage due to the flocculation and aggregation of clay particles. This occurs when humus, a product of organic matter decomposition, forms bridges that bond the clay particles together and forms particles sometimes referred to as pseudosand (Brady and Weil 2002).

The chemical properties of soil are equally important for maintaining healthy Taxus. The suggested soil $\mathrm{pH}$ for Taxus ranges from 6.0 to 7.0 (Hibben and Cahilly 1996; Fraedrich 1999; Halcomb 2012; Kaiser and Ward 2013). In a study by Gilliam et al. (1985), Taxus cuspidata 'Densiformis' was grown in a fine sandy loam with three $\mathrm{pH}$ levels of 5.2, 5.8, and 6.2. At the highest $\mathrm{pH}$, plants had greater growth indices, and there was a significant effect of $\mathrm{pH}$ on tissue zinc $(\mathrm{Zn})$ and manganese $(\mathrm{Mn})$ concentrations. In the first year of the three-year study, when $\mathrm{pH}$ treatments decreased from 6.2 to 5.2 , tissue nutrient concentration of $\mathrm{Mn}$ increased from 525 to 4150 ppm, which is a $690 \%$ increase. This trend also occurred in years two and three of the study at a similar magnitude. Tissue $\mathrm{Zn}$ concentrations were similarly affected by soil $\mathrm{pH}$. However, the magnitude was much lower, and concentrations ranged from 35 to $230 \mathrm{ppm}$. These types of results would be expected as the availability of Mn and $\mathrm{Zn}$ in soil increases as soil pH decreases (Marschner 1995). There was little to no effect of soil $\mathrm{pH}$ on all other tissue elements tested [nitrogen $(\mathrm{N})$, phosphorus $(\mathrm{P})$, calcium $(\mathrm{Ca})$, magnesium $(\mathrm{Mg})$ and iron $(\mathrm{Fe})]$.

Toxicity of $\mathrm{Mn}$ and/or $\mathrm{Zn}$ has been considered as a potential cause of decline and needle chlorosis of Taxus (Hibben and Cahilly 1996). In most plants, $\mathrm{Zn}$ and Mn toxicity cause leaf chlorosis of younger leaves (Marschner 1995). In the study at NYBG, soil $\mathrm{pH}$ was below suitable range for most of the Taxus tested and tissue $\mathrm{Mn}$ and $\mathrm{Zn}$ concentrations averaged 589 and 189 ppm, respectively. No correlation was found between chlorotic needles and the concentration of either of these nutrients. However, the manifestation of Mn or Zn toxicity specifically on Taxus has not been determined. Furthermore, the average tissue concentrations of $\mathrm{Mn}$ and $\mathrm{Zn}$ fell within the sufficiency range for $T$. $\times$ media 'Hicksii' published by Mills and Jones (1996). This publication is the only known reference for sufficient tissue nutrient concentration of Taxus, which provides the ranges for $T . \times$ media 'Hicksii' and average concentrations for $T$. baccata (Table 1). These averages and ranges can be helpful when making decisions on fertilization rates and practices. Further research to develop ranges for other species and cultivars is needed.

Deficiencies of $\mathrm{N}, \mathrm{K}, \mathrm{S}$, or $\mathrm{Mg}$ are also known to cause leaf chlorosis (Marschner 1995). For Taxus production and maintenance in the landscape, fertilizer recommendations are limited. Halcomb (2012) recommends high $\mathrm{P}$ and $\mathrm{K}$ fertilization rates during production and three to four applications of $\mathrm{N}$ through the growing season. The $\mathrm{N}$ should not be applied too late in the season to avoid the potential of winter injury on succulent tissue. A study with young Taxus $\times$ media 'Hicksii' in containers indicated fertilization with $380 \mathrm{ppm} \mathrm{N}$ at each irrigation reduced growth compared to 120 and $192 \mathrm{ppm} \mathrm{N}$ (Khatamian and Lumis 1982). This indicates high $\mathrm{N}$ rates should not be used when growing Taxus. In the landscape, fertilization rates should be lower unless maximum growth rates are preferred. Soil tests should be performed every one to two years to determine the type and timing of fertilizer applications. These tests can also be done in conjunction with tissue testing, particularly in cases where plants are declining or when attempting to restore sufficient nutrient concentrations. Conducting these two tests at the same time will provide a more holistic view of the nutritional status of the plant and soil. The local soil testing laboratory should provide 
the sufficiency ranges for nutrients in the soil and possibly fertilizer recommendations. These recommendations depend on the laboratory procedures, plant, soil type, soil $\mathrm{pH}$, soil electrical conductivity, nutrient ratios, cation exchange capacity, and organic matter content. It is important to use the same laboratory, sampling techniques, and testing procedures to properly observe changes over time.

Table 1. Average concentration for Taxus baccata and sufficiency range for Taxus $\times$ media 'Hicksii' for dry weight tissue nutrients in 5 to $7.5 \mathrm{~cm}$ summer collected terminal cuttings (Mills and Jones 1996).

\begin{tabular}{lll}
\hline & Taxus baccata & Taxus $\times$ media 'Hicksii' \\
\hline Dry weight concentration of macronutrients $(\%)$ \\
Nitrogen & 1.98 & $2.0-4.0$ \\
Phosphorus & 0.21 & $0.17-0.40$ \\
Potassium & 1.21 & $1.00-2.00$ \\
Calcium & 0.60 & $0.60-1.25$ \\
Magnesium & 0.16 & $0.20-0.30$ \\
Sulfur & 0.14 & $0.15-0.17$ \\
Dry weight concentration of micronutrients $(\mathrm{ppm})$ \\
Iron & 36 & $75-250$ \\
Manganese & 490 & $100-650$ \\
Boron & 17 & $20-65$ \\
Copper & 4 & $10-30$ \\
Zinc & 114 & $25-300$ \\
Molybdenum & 0.30 & $0.12-0.50$ \\
\hline
\end{tabular}

\section{ADDITIONAL THREATS}

In addition to soil, water, and disease management, some insects can damage Taxus. Major insect pests include Otiorhynchus wistariae (black vine weevil), Otiorhynchus ovatus (strawberry root weevil), Cecidophyopsis psilaspis (Taxus bug mite), and Pentamerismus taxi (false spider mite) (Hibben and Cahilly 1996; Fraedrich 1999). Otiorhynchus wistariae is the most common and attacks Taxus by leaving semicircular holes or notches along the edges of the needles. The grub-like larvae may feed on roots, which could also cause needle chlorosis and dieback (Kaiser and Ward 2013). The other three pests tend to cause needle stippling (Hibben and Cahilly 1996). Many times, insect populations are at tolerable levels, but levels can occasionally reach a threshold where pest management is necessary.

Taxus in the landscape are often situated near walkways and roads. De-icing salts applied to these areas to manage snow and ice can injure roots and foliage. Roots can be damaged by the high salt content that remains in soil near treated areas. Foliar symptoms may not be apparent until plant growth begins in the spring when needles will rapidly turn brown, which typically occurs on areas of the plant nearest to the salt applications (Kaiser and Ward 2013).

\section{SUMMARY AND RECOMMENDATIONS}

In review, the largest threat to Taxus in the landscape is saturated soils and Phytophthora root rot. Choosing the proper location and soil upon planting will lead to healthier, longer-lived plants. In situations where established plants are growing in areas prone to saturation, strategies should be implemented to reduce the degree and longevity of the saturated soils. This can be accomplished by grading the soil or installing swales to reduce the flow of water to the area of concern; redirecting downspouts; incorporating organic matter into the soil, which will help flocculate and aggregate soil particles to improve drainage; installing French drains to move water away from the area at a faster rate; and reducing the potential of compaction from foot and vehicle traffic. Excessive mulching should also be avoided, since this will reduce the rate that soil dries, and coarse mulch should be preferred compared to shredded products that can compact and hold water (Smiley et al. 1999). Although wet conditions should be avoided with Taxus, plants can also suffer from periods of drought. Irrigation should be used during dry periods, particularly with newly installed plants.

If saturated soil is a problem, the likelihood of infection by Phytophthora is much greater. Precautions should be taken to avoid the potential for infection. Phytophthora can be spread by soil cultivation equipment, irrigation water, or by using infected plant material (Gallo et al. 2007). Phytophthora cinnamomi, in particular, can readily be spread by irrigating with creek and pond water collected as runoff from infected areas (Mebalds et al. 1996). Even if there have not been host plants in the area, P. cinnamomi has appreciable competitive saprophytic ability and oospores can persist for long periods in fallow soil (Zentmyer and Mircetich 1966; Smiley et al. 1999). Additionally, disturbing soil during construction projects can damage roots and make plants more susceptible to disease.

If plants in the landscape are thought to be infected with Phytophthora, testing should be done through the local plant disease diagnostic clinic. Each may have their own procedure for collecting samples and testing. ImmunoStrip ${ }^{\oplus}$ test kits are also available to 
do the testing in-house (Agdia Inc. Elkhart, Indiana, U.S.). If tests are positive, chemical control methods can be used to help prevent loses. Fosetyl-Al, metalaxyl, phosphorous acid, and mefenoxam have been shown to be effective against $P$. cinnamomi on woody plants. Benson (1990) showed both fosetyl-Al and metalaxyl to be effective in controlling this disease on Hinodegiri azaleas [Rhododendron obtusum (Lindl.) Planch] in containers and landscape beds. In the three-year study, there was no difference in growth between inoculated plants treated with either chemical compared to uninoculated control plants. Furthermore, the mortality rates of inoculated untreated plants were six times greater, and plants were less than half the size of those in all the other treatments. However, in all four treatments, rates of infection did increase over time. In a field study with Fraser fir [Abies fraseri (Pursh) Poir], application of fosetyl-Al (three times per growing season) or mefenoxam (two times per season) reduced mortality rates over a three-year period (Benson et al. 2006). Phytophthora cinnamomi is also a major pest on avocado, and fosetyl- $\mathrm{Al}$ or phosphorous acid have been shown to be the most effective among chemical controls (Gallo et al. 2007).

Application of chemicals can be done to control the rate of infection or as a preventive measure. Preventive treatment is recommended on important specimen trees and for plants subject to saturated soils since $P$. cinnamomi can progress rapidly from undetectable levels (Smiley et al. 1999). The first chemical application of the growing season should be done just before the fungus becomes active, which can be determined by monitoring soil temperatures. Smiley et al. (1999) indicates that infection is favored when the temperature of the soil exceeds $18^{\circ} \mathrm{C}$, and Waterhouse (1963) indicates P. cinnamomi has an optimum growth temperature of $26^{\circ} \mathrm{C}$. One to two repeat applications are recommended through the growing season and surrounding susceptible plants should be treated as well. An alternative to chemical control is the use of beneficial microorganisms. Zentmyer and Mircetich (1966) indicate antagonistic soil microorganisms can reduce the presence and growth of pathogenic Phytophthora. However, current research on this topic for landscape plants is limited and the effectiveness of applying beneficial microorganisms for disease management in the landscape is untested and unknown.
Water, disease, and nutrient management are priorities to ensure the longevity and health of Taxus in the landscape. When installing new plants, it is critical to select a site that is not prone to saturation and to determine if soil physical and chemical properties are appropriate. Monitoring plants through soil and tissue testing will help growers and gardeners make informed management decisions to protect plants from stress, which will ensure plants reach the maximum potential and are impactful in the landscape.

\section{LITERATURE CITED}

Agrios, G. 1997. Plant Pathology, fourth edition. Academic Press, San Diego, California, U.S. pp. 270-274.

Benson, D.M. 1986. Relationship of soil temperature and moisture to development of Phytophthora root rot of azalea. Plant Disease 69:1049-1054.

Benson, D.M. 1990. Landscape survival of fungicide-treated azaleas inoculated with Phytophthora cinnamomi. Plant Disease 74:635-637.

Benson, D.M., J.R. Sidebottom, and J. Moody. 2006. Control of Phytophthora root rot in field plantings of Fraser fir with fosetyl-al and mefenoxam. Plant Management Network. Accessed 05/22/2014. $<$ www.ces.ncsu.edu/fletcher/programs/xmas/research/pest_management/disease/benson_side2006.pdf>

Brady, N., and R. Weil. 2002. The Nature and Properties of Soils, 13th edition. Prentice Hall, Upper Saddle River, New Jersey, U.S. pp. 150.

Crandall, B.S. 1936. Root disease of some conifers and hardwoods caused by Phytophthora cambivora (P. cinnamomi). The Plant Disease Reporter 20:202-204.

Davis J., and D. Whiting. 2013. Choosing a soil amendment. Colorado State University Extension. Fact Sheet No. 7.235.

Dumrose, R.K., and R.L. James. 2005. Root diseases in bareroot and container nurseries of the Pacific Northwest: Epidemiology, management, and effects on outplanting performance. New Forests 30:185-202.

Ellis, M.A., S.A. Miller, and K.D. Cochran. 1993. First report of Phytophthora root rot caused by Phytophthora cinnamomi. Plant Disease 77:537.

Fraedrich, B.R. 1999. Taxus disorders. Bartlett Tree Research Laboratories Technical Report. TR85:1-2.

Gallo, L., F. Siverio, and A.M. Rodríguez-Pérez. 2007. Thermal sensitivity of Phytophthora cinnamomi and long-term effectiveness of soil solarisation to control avocado root rot. Annals of Applied Biology 150:65-73.

Gilliam, C.H., J.T. Eason, and C.E. Evans. 1985. Effects of soil pH on four field-grown nursery crops. Journal of Environmental Horticulture 3:136-139.

Halcomb, M. 2012. Taxus (Yew) field production. University of Tennessee Extension. Accessed 05/22/2014. <www.utextension.utk. edu/mtnpi/handouts/Production\%20Guides/Yew_or_Taxus.pdf >

Hibben, C.R., and A.W. Cahilly. 1996. Decline of Taxus in the New York Botanical Garden: Current status, contributing factors, and recommendations. New York Botanical Garden, New York City, New York, U.S. 
Hillel, D. 2008. Soil in the Environment: Crucible of Terrestrial Life. Academic Press, Burlington, Massachusetts, U.S. 56 pp.

Kaiser, C.A., and N.A. Ward. 2013. What's Wrong with My Taxus? Cooperative Extension Service University of Kentucky College of Agriculture, Food and Environment 52:1-4.

Khatamian, H., and G. Lumis. 1982. Influence of shade, media, and fertility on growth of Taxus. Journal of Arboriculture 8:247-249.

Marschner, H. 1995. Mineral Nutrition of Higher Plants. Academic Press, San Diego, California, U.S. pp. 310, 333, 362, 462, 644-645.

Matheron, M.E., and S.M. Mircetich. 1985. Control of Phytophthora root and crown rot and trunk canker in walnut with metalaxyl and fosetyl al. Plant Disease 69:1042-1043.

Mebalds, M., A. van der Linden, M. Bankier, and D. Beardsell. 1996. Using ultra violet radiation and chlorine dioxide to control fungal plant pathogens in water. The Nursery Papers 5:1-2.

Mills H., and J. Jones. 1996. Plant Analysis Handbook II: A Practical Sampling, Preparation, Analysis, and Interpretation Guide (revised). MicroMarco Publishing Inc., Athens, Georgia, U.S. pp. 209.

Schreiber, L.R., and R.J. Green. 1959. Die-Back and Root Rot Disease of Taxus spp. in Indiana. The Plant Disease Reporter 43:814-817.

Smiley, E.T., B.R. Fraedrich, and T.R. Martin. 1999. Phytophthora Root Rot and Collar Rot of Landscape Plants. Bartlett Tree Research Laboratories Technical Report 63:1-3.

Waterhouse, G. 1963. Key to species of Phytophthora de Bary. Commonwelth Mycological Institute Mycology Papers 92:1-22.

Zentmyer, G.A., and S. Mircetich. 1966. Saprophytism and persistence in soil by Phytophthora cinnamomi. Phytopathology 36:710-712.

Zentmyer, G.A. 1981. The effect of temperature on growth and pathogenesis of Phytophthora cinnamomi and on growth of its avocado host. Phytopathology 71:925-928.

\section{Matthew D. Taylor \\ Longwood Gardens \\ Kennett Square, Pennsylvania 19348, U.S. mtaylor@longwoodgardens.org}

Zusammenfassung. Mindestens drei große Gärten oder Arboreten in den USA haben Perioden mit signifikantem Absterben und Rückgang von alten Taxus (Eiben) in der Landschaft erfahren. Die sichtbaren Symptome auf den betroffenen Pflanzen wurden als Chlorosis der Nadeln, partielle Entlaubung und Absterben von einzelnen ästen beschrieben. Gelegentlich starben ganze Pflanzen, aber diese wurden typischerweise vor Erreichen dieses Zustands entfernt. Es gibt nur begrenzte Informationen über die Pflege von ausgewachsenen Eiben in der Landschaft. Das Ziel dieses Artikels ist eine Übersicht der Literatur zur Pflege von Taxus und eine Nutzung dieser Informationen zur Entwicklung der besten Pflegemaßnahmen für Taxus in der Landschaft. Die Bodenfeuchte ist der kritische Faktor für Gesundheit von Pflanzen in der Landschaft. Gesättigte Böden kreieren anaerobe Bedingungen für Wurzeln und kreieren damit ideale Voraussetzungen für die Wurzelinfektion mit Phytophthora cinnamomi, dem Hauptwurzelpathogen von Taxus. Nach der Pflanzung sollte die Bewässerung gesteuert werden, um eine Sättigung zu vermeiden. Das Management hinsichtlich der Nährstoffversorgung ist noch nicht vollständig verstanden. Es wird empfohlen, einen $\mathrm{pH}$ von 6 bis 7 basierend auf Messungen von Boden und Gewebe zu erhalten. Es braucht mehr Forschung, um optimale Düngungsempfehlungen und angemessene Nährstoffkonzentrationen in Gewebe und Böden zu bestimmen. Wenn die
Pflanzen erste Symptome zeigen, sollte der Boden auf P. cinnamomi getestet werden. Wenn der Pilz präsent ist, sollten entsprechende chemische Kontrollen verwendet werden.

Résumé. Au moins trois grands jardins ou arboretums aux États-Unis ont connu des périodes de déclin significatif et de mortalité d'ifs matures (Taxus). La chlorose des aiguilles, la défoliation partielle et la mort de certaines des branches étaient les symptômes qui apparaissaient sur les végétaux en déclin. Tous ces végétaux finissaient par mourir, mais ils étaient généralement abattus avant que ce stade ne soit atteint. Les connaissances sur la gestion d'ifs matures en ornementation sont limitées. L'objectif de cet article est d'effectuer une revue de littérature sur les pratiques culturelles des ifs et d'utiliser cette information pour développer de meilleures pratiques de gestion quant aux ifs ornementaux. L'humidité du sol est le facteur le plus critique pour la santé des plantes d'ornementation. Les sols saturés provoquent des conditions anaérobiques pour les racines créant ainsi un environnement idéal pour l'infection des racines par le Phytophthora cinnamomi, principal pathogène des racines affectant les ifs. Au moment de la plantation, un choix judicieux du site et la présence d'un sol bien drainé sont cruciaux pour la survie à long terme de ces plantes. Après la plantation, l'irrigation doit être gérée de manière à éviter la saturation du sol. La gestion nutritionnelle est mal comprise. Le maintien d'un pH de 6,0 à 7,0 et la fertilisation des plantes en fonction du résultat des analyses du sol et des tissus sont recommandés. D'autres recherches doivent être effectuées pour déterminer les taux optimaux de fertilisation et la concentration cible appropriée de nutriments dans les tissus et dans le sol. Quand les plantes deviennent symptomatiques, le sol doit être analysé pour détecter la présence de P. cinnamomi. Des contrôles chimiques appropriés devraient être utilisés si la présence de ce champignon est confirmée.

Resumen. Al menos tres grandes jardines o arboreta en los EE.UU. han experimentado períodos de declive significativo y la muerte de Taxus maduros (tejos). Los síntomas que aparecen en plantas se describen como clorosis de las agujas, defoliación parcial y la muerte de algunas de las ramas. Con el tiempo toda la planta puede morir pero se eliminan normalmente antes de llegar a esta etapa. La información sobre la gestión de Taxus maduros en el paisaje es limitada. El objetivo de este artículo es revisar la literatura sobre las prácticas culturales de Taxus y utilizar la información para desarrollar las mejores prácticas de gestión para Taxus en el paisaje. La humedad del suelo es el factor más crítico para la salud de las plantas en el paisaje. Los suelos saturados crean condiciones anaerobias para las raíces y un ambiente ideal para la infección de la raíz por Phytophthora cinnamomi, el principal patógeno de raíz que afecta Taxus. Durante la plantación, la selección del sitio adecuado y un suelo bien drenado son cruciales para la supervivencia a largo plazo de las plantas. Después de la plantación, el riego debe programarse para evitar el suelo saturado. El manejo desde un punto de vista nutricional es poco conocido. Se recomienda mantener un $\mathrm{pH}$ apropiado de 6.0 a 7.0 y la fertilización en base a pruebas de suelo y tejido. Se requiere más investigación para determinar las tasas de fertilización óptima y la concentración de minerales adecuada en el tejido y en el suelo. Cuando las plantas se vuelven sintomáticas, el suelo debe ser probado para P. cinnamomi. Si el hongo está presente, se deben utilizar los controles químicos apropiados. 